\title{
Fertility preservation in women with cervical, endometrial or ovarian cancers
}

Michael Feichtinger ${ }^{1,2,4}$ and Kenny A. Rodriguez-Wallberg $3,4^{*}$

\begin{abstract}
Background: Although cancer in general affects an aged population, a significant number of women develop cancer at childbearing age. Long-term survival rates after gynecological cancer, especially in young patients are increasing and all quality-of-life aspects, including preservation of fertility have become of major relevance.

Outcomes: Surgical techniques aimed at sparing reproductive organs and preserving fertility have been developed for women presenting with gynecological cancer found at early stages. Indications for fertility-sparing surgery are in general restricted to women presenting with a well-differentiated low-grade tumor in its early stages or with low malignant potential. Up to now, use of fertility-sparing techniques in well-selected patients has not been shown to affect overall survival negatively and fertility outcomes reported have been favorable. Still larger amounts of data and longer follow-up periods are needed. Several current fertility-sparing cancer treatments may result in sub-fertility and in those cases assisted reproductive techniques are indicated. Overall quality of life has been satisfactory in cancer patients after fertility-sparing surgery.

Conclusions: Fertility-sparing surgery is a viable tool to enable gynecological cancer patients of young age to fulfill their family building without impairment of oncological outcome. Cancer patients of reproductive age should undergo fertility counseling to analyze this sensitive subject. Further studies are needed to investigate the role of fertility-sparing treatment and combined adjuvant therapy in higher-grade cancers.
\end{abstract}

Keywords: Fertility preservation, Gynecological cancer, QoL, IVF, Cervical cancer, Ovarian cancer, Endometrial cancer, Pregnancy

\section{Background}

The overall cancer risk in women below the age of 39 years is estimated to be one in 39 [1]. Of all gynecological cancer cases, young women comprise $2 \%$ of cervix cancer cases, $5 \%$ of endometrial cancers and up to approximately $12 \%$ of ovarian cancers [1]. Five-year survival rates range from $46 \%$ in ovarian cancer to more than $80 \%$ in endometrial cancer and over $90 \%$ in cases of borderline ovarian tumors $[2,3]$. Infertility following cancer treatment has been recognized as a main concern as regards quality of life (QoL) in cancer patients $[4,5]$. As a result of improved long-term survival rates in young people, all QoL aspects are of major importance. Additionally, due to

\footnotetext{
* Correspondence: kenny.rodriguez-wallberg@karolinska.se

${ }^{3}$ Department of Oncology - Pathology, Karolinska Institutet, Stockholm, Sweden

${ }^{4}$ Department of Obstetrics and Gynecology, Section of Reproductive

Medicine, Karolinska University Hospital, Novumhuset Plan 4, SE-141 86

Stockholm, Sweden

Full list of author information is available at the end of the article
}

current social trends, childbearing nowadays is delayed, hence an increasing number of women that present with cancer at a young age might have not yet fulfilled their family building plans and will be interested in undergoing treatments that would preserve their chances to have children in the future [6]. Most oncologic treatments have detrimental effects on female reproductive potential, in particular those including chemotherapy with agents of high gonadotoxicity, or radiation therapy in a field involving the ovaries, the uterus and the vagina, which may be compromised and damaged by direct irradiation [7]. The resumption of menstrual cycles indicates that some ovarian function is maintained, but it does not guarantee fertility, and early onset of menopause in women previously treated for cancer is a common finding [7-9].

Surgery is currently the most effective treatment for cancer and eventually up to $100 \%$ of patients may be cured when complete removal of a tumor is achieved. Surgery may also be indicated for treatment of 
premalignant disease of the cervix or the endometrium in female patients, as cancer prophylaxis. Conization, for example, may lead to completely disease-free follow-up, but it may induce sub-fertility by affecting the normal function of the cervix and its glandular secretion. Infertility induced by such forms of intervention may be overcome by treatments involving assisted reproductive technologies, such as intrauterine insemination or in vitro fertilization, IVF.

In gynecologic oncologic surgery, there has been gradual development of fertility-sparing surgery with the aim of preserving the reproductive organs. Survival should not be compromised and thus indications are restricted to patients of a young age with a desire to preserve fertility and presenting with a well-differentiated cervical, ovarian or endometrial low-grade tumor in its early stages or with low malignant potential.

In this article we will discuss indications for fertilitysparing methods available to women with gynecological cancer, and up-to-date data on safety and efficacy as regards oncologic outcomes and reproductive outcomes including obstetric outcomes and quality of life.

\section{Cervical cancer}

Cervical cancer makes up $1.5 \%$ of all new cancer cases in females. In 2015, 12900 patients with a median age of 49 years had newly diagnosed cervical cancer in the US. Of these, $38.5 \%$ were under the age of 45 years $[1,2]$. The different approaches regarding fertility-sparing surgery in cases of cervical cancer are summarized in Table 1.

In cases of micro-invasion $(<3 \mathrm{~mm})$, FIGO stage IA1, cervical carcinoma can be treated with simple large loop excision of the transformation zone (LLETZ), without further affecting fertility potential. Compared with this approach, hysterectomy has not been associated with improved survival rates if no lymph vascular space invasion and negative cancer margins are confirmed [10]. This approach can be applied in micro-invasive squamous cell carcinoma as well as adenocarcinoma, with similar outcomes [11].

In patients affected by cervical cancer at FIGO stages IA2-IB1 who wish to preserve fertility, radical trachelectomy with pelvic lymphadenectomy (confirming negative lymph node status) is the treatment of choice [12, 13]. Radical trachelectomy was first described by Dargent in 1994 [14] and it represents the most established surgical procedure for fertility preservation in women. The procedure has been reported for the treatment of squamous cell carcinomas and adenocarcinomas, with similar outcomes [15]. As operative techniques, vaginal, laparascopic, abdominal and robot-assisted trachelectomy have been described [13]. Long-term oncologic outcomes of trachelectomy seem not to differ compared with radical hysterectomy, and a long-term survival rate of $98.4 \%$ and a relapse rate of only $4.5 \%$ have been reported $[16,17]$.
Perioperative complications have also been similar when compared with radical hysterectomy [13]. Further development of non-invasive nuclear methods to identify lymph nodes in patients with early-stage cervical cancer might improve future patient selection for this type of fertility-sparing surgery [18].

After trachelectomy, over $60 \%$ of tissue samples have demonstrated absence of residual tumor [19]. Therefore, conization in combination with laparoscopic lymphadenectomy has also been described as an appropriate procedure in selected patients presenting with early-stage cervical cancer (FIGO IA2 and IB1) and tumors $<20 \mathrm{~mm}$. Women thus treated have succeeded in conceiving in $47 \%$ of cases and the 5-year disease free survival reported of $97 \%$ $[20,21]$. However, although data are promising, the number of cases published is still small and further research is needed to implement this technique as a clinical routine.

In cases of more advanced disease with a tumor size $>2 \mathrm{~cm}$, initial neoadjuvant chemotherapy followed by radical trachelectomy and lymphadenectomy has been suggested by some authors [22, 23]. This approach has been shown to correlate with high fertility rates and no differences in oncologic outcome compared with immediate trachelectomy without chemotherapy [24]. Because of few reported cases and no long-term follow-up outcomes, this procedure should still be regarded as experimental.

In selected cases where radiotherapy or chemoradiation are necessary, the ovaries can be protected by ovarian transposition to remove them from the radiation field [25-27]. However, depending on the radiation dose and radiation scatter, the efficacy of this procedure has been reported to be about $50 \%[28,29]$. If assisted reproductive treatments involving IVF are needed thereafter, the ovaries are often difficult to access for ovum pickup. Ovarian stimulation in connection with subsequent cryopreservation of oocytes or embryos before cancer treatment is thus indicated in such cases [6,30-34]. However, even if ovarian function is preserved, or oocytes or embryos have been cryopreserved, irradiation of the uterus may cause irreversible damage. Although cases of good obstetric outcome have been reported after fertility preservation among women with a heavily irradiated uterus [35], unsuccessful results should be expected and in many cases surrogacy will be necessary [36].

If oocyte or embryo cryopreservation are not feasible, the emerging technique of cryopreserving ovarian tissue for later retransplantation might serve as a viable tool to preserve fertility in some cancer patients. Heterotopic and orthotopic transplantation sites have been described, with resumption of ovarian function [35, 37-39]. Up to now more than 60 children have been born worldwide after ovarian tissue transplantation [39, 40].

In cases of ovarian tissue cryopreservation, concerns have been raised as regards the risk of reseeding cancer 
Table 1 Fertility-sparing interventions in women with cervical or endometrial cancer

\begin{tabular}{|c|c|c|c|c|c|}
\hline Diagnosis & Type of Surgery & Description & $\begin{array}{l}\text { Reproductive and Obstetric } \\
\text { Outcomes }\end{array}$ & Oncologic Outcome & Quality of Life \\
\hline $\begin{array}{l}\text { Cervical Cancer } \\
\text { FIGO Stage IA1 } \\
\text { (microinvasion } \\
<3 \mathrm{~mm} \text { ) }\end{array}$ & $\begin{array}{l}\text { Large loop excision of the } \\
\text { transformation zone (LLETZ) } \\
\text { or conization if absence of } \\
\text { lymph vascular space invasion } \\
\text { and negative margins are } \\
\text { confirmed }\end{array}$ & $\begin{array}{l}\text { Complete resection of } \\
\text { the transformation zone }\end{array}$ & $\begin{array}{l}\text { No fertility impairment reported. } \\
\text { OR } 1.7 \text { for preterm delivery and } \\
2.69 \text { for premature rupture of } \\
\text { membranes; associated with } \\
\text { resection size. No difference in } \\
\text { neonatal outcome [130] }\end{array}$ & $\begin{array}{l}\text { Similar oncologic outcomes } \\
\text { reported in comparison with } \\
\text { hysterectomy [10] }\end{array}$ & $\begin{array}{l}\text { Conization has not been } \\
\text { associated with reduced } \\
\text { quality of life or sexual } \\
\text { satisfaction [49] }\end{array}$ \\
\hline $\begin{array}{l}\text { FIGO Stages } \mid \mathrm{A} 2 \\
\mathrm{IB} 1<2 \mathrm{~cm}\end{array}$ & $\begin{array}{l}\text { Cervical conization } \\
\text { and laparoscopic } \\
\text { lymphadenectomy }\end{array}$ & $\begin{array}{l}\text { Conization of the cervix } \\
\text { and laparoscopic pelvic } \\
\text { lymphadenectomy }\end{array}$ & $\begin{array}{l}\text { Spontaneous conceptions of } \\
\text { about } 47 \% \text {. Prematurity rates } \\
\text { reported with } 14.3 \% \text { of infants } \\
\text { born }<32 \text { weeks of gestation [21] }\end{array}$ & $\begin{array}{l}\text { Excellent rates of 5-year } \\
\text { disease-free survival (97\%) [21] }\end{array}$ & $\begin{array}{l}\text { Conization with laparoscopic } \\
\text { lymphadenectomy has not } \\
\text { been associated with } \\
\text { reduced quality of life or } \\
\text { sexual satisfaction [49] }\end{array}$ \\
\hline $\begin{array}{l}\text { FIGO Stages IA2, } \\
\text { IB1 }\end{array}$ & $\begin{array}{l}\text { Radical trachelectomy. } \\
\text { Techniques described for } \\
\text { vaginal, abdominal, } \\
\text { laparoscopic or robotic } \\
\text { trachelectomy }\end{array}$ & $\begin{array}{l}\text { Resection of the cervix } \\
\text { and surrounding parametria } \\
\text { with conservation of the } \\
\text { uterus and the ovaries, pelvic } \\
\text { lymphadenectomy }\end{array}$ & $\begin{array}{l}\text { Spontaneous pregnancy rates } \\
\text { in }>60 \% \text { of patients } \\
\text { Preterm deliveries with } 28 \% \\
\text { of infants born }<32 \text { weeks of } \\
\text { gestation }[17,132]\end{array}$ & $\begin{array}{l}\text { Rates of recurrence and mortality } \\
\text { are comparable with those } \\
\text { described for similar cases treated } \\
\text { with radical hysterectomy; long-term } \\
\text { survival } 98.4 \% \text {. Low relapse rates } \\
(4.5 \%)[16,17]\end{array}$ & $\begin{array}{l}\text { Lower quality of life than } \\
\text { healthy controls but similar } \\
\text { to radical hysterectomy } \\
\text { No significant impairment } \\
\text { in sexual satisfaction } \\
\text { Long-term bladder } \\
\text { complications (40\%) and } \\
\text { lymphedema (10\%) [46-48] }\end{array}$ \\
\hline $\begin{array}{l}\text { FIGO Stage IB1, } \\
>2 \mathrm{~cm}\end{array}$ & $\begin{array}{l}\text { Neoadjuvant chemotherapy } \\
\text { followed by radical } \\
\text { trachelectomy }\end{array}$ & $\begin{array}{l}\text { Three cycles of paclitaxel, } \\
\text { cisplatin and ifosfamide } \\
\text { followed by radical } \\
\text { trachelectomy }\end{array}$ & $\begin{array}{l}\text { After neoadjuvant chemotherapy } \\
\text { and trachelectomy up to } 86 \% \\
\text { live-birth rates with } 86 \% \\
\text { spontaneous conception rate } \\
\text { [134] }\end{array}$ & $\begin{array}{l}\text { Reported relapse rate of } 7.6 \% \\
\text { with } 90 \% \text { survival }[23,24]\end{array}$ & Lack of data \\
\hline $\begin{array}{l}\text { Endometrial Cancer } \\
\text { FIGO stage IA }\end{array}$ & $\begin{array}{l}\text { Medical conservative treatment } \\
\text { with hormone therapy using } \\
\text { progestational agents either } \\
\text { orally or by IUD for }>6 \text { months } \\
\text { Myometrial evaluation by MRI } \\
\text { should be performed to confirm } \\
\text { absence of myometrial infiltration } \\
\text { and no extrauterine involvement } \\
{[52] \text {. }}\end{array}$ & $\begin{array}{l}\text { Follow-up by hysteroscopic } \\
\text { exams with endometrial } \\
\text { biopsies every } 3 \text { months }\end{array}$ & $\begin{array}{l}\text { Pregnancy rates of }>60 \% \\
\text { Uneventful pregnancies } \\
\text { reported }[63,72]\end{array}$ & $\begin{array}{l}\text { Positive response rate to progesterone } \\
\text { treatment of } 72 \% \text {. Either oral or local } \\
\text { IUD treatments proposed, as well as } \\
\text { a combination of both. Relapse rate } \\
\text { of } 50 \% \text {. A second round of progesterone } \\
\text { therapy in cases of relapse has been } \\
\text { associated with a response rate of up } 89 \% \\
\text { [55, } 57,60,62] \text {. A levonorgestrel IUD has } \\
\text { shown greater regression on histology, } \\
\text { lower relapse rates and lower rates of } \\
\text { hysterectomy for treatment of complex } \\
\text { endometrial hyperplasia vs. oral } \\
\text { progesterone [57-59]. }\end{array}$ & $\begin{array}{l}\text { Levonorgestrel IUD treatment } \\
\text { has been associated with fewer } \\
\text { systemic side effects compared } \\
\text { with oral progesterone } \\
\text { administration }[79,80]\end{array}$ \\
\hline
\end{tabular}

Modified from: Rodriguez-Wallberg KA, Oktay K. Fertility preservation during cancer treatment: clinical guidelines. Cancer management and research. 2014:6:105-17

Abbreviations: FIGO International Federation of Gynecology and Obstetrics, LLETZ large loop excision of the transformation zone; IUD intrauterine device, OR odds ratio 
cells at time of retransplantation, if they are present in the tissue preserved. Ovarian metastasis has been reported in $6 \%$ of patients with adenocarcinoma of the cervix and $1 \%$ of patients with squamous cell carcinoma [41]. Nevertheless, of five published cases of retransplantation of ovarian tissue in women with previous cervical carcinoma, none have resulted in relapse [32, 37].

For women undergoing radical surgery with hysterectomy, the chance of childbearing is only possible by means of a womb transplant. Successful results have been obtained by a Swedish team that has led this project over many years [42] and these procedures are expected to extend to several US centers in the future [43].

Data on assisted reproductive treatments after cervical cancer are scarce. In one study a prevalence of infertility of $13.5 \%$ among patients with previous vaginal trachelectomy was reported [44]. Of these, cervical factor infertility was found in about $40 \%$ of cases, indicating a need for intrauterine insemination as the first-line treatment approach. In other series of cases reported, $80 \%$ of women conceived after subsequent fertility treatments [44, 45].

Regarding quality of life, compared with women with radical hysterectomy who had at least one ovary, patients who had undergone trachelectomy had similar sexual satisfaction and quality of life after surgery [46]. However, another study group reported low sexual satisfaction in the first year after surgery compared with healthy subjects and patients after abdominal hysterectomy. However, this effect decreased over time and after one year these patients had similar sexual satisfaction (but with a persistently reduced QoL) when compared with healthy controls [47]. These results are consistent with those of another study reporting bladder-emptying problems in more than $40 \%$ and lymphedema in more than $10 \%$ of cases, reflecting a lower QoL in patients after vaginal or abdominal trachelectomy compared with healthy controls [48].

Cold-knife conization and laparoscopic lymphadenectomy, on the other hand, are not associated with reduced sexual satisfaction and quality of life [49].

\section{Endometrial cancer}

Endometrial cancer comprises $7.1 \%$ of all new cancer cases in females. In the US, 55,000 new cases of endometrial cancer cases were expected in 2015, with a median patient age of 62 years. Seven percent of endometrial cancer patients are under the age of 45 years [1,2]. Patients at higher risk of presenting endometrial carcinoma are overweight women and those with polycystic ovarian syndrome (PCOS) [50]. The standard treatment of endometrial cancer involves hysterectomy and bilateral salpingo-oophorectomy, due to the hormonal sensitivity of endometrial tumors [51]. In endometrial cancer IA without infiltration to the myometrium and no extrauterine involvement, conservative treatment can be offered to women who wish to maintain fertility. To counsel a women wishing fertility-sparing treatment options properly, myometrial evaluation by MRI should be performed [52].

For women with early-stage endometrial cancer, treatments involving use of progesterone either orally $(600 \mathrm{mg}$ medroxyprogesterone acetate daily or $160 \mathrm{mg}$ megestrol acetate daily) or delivered by an intrauterine device (levonorgestrel-releasing IUD) have been described. The combination of IUD and oral progesterone treatment has also been proposed [53]. In retrospective studies a $72 \%$ positive response rate to treatment has been reported [54-56]. In prospective studies, the treatment of complex endometrial hyperplasia using a levonorgestrel IUD has been shown to achieve greater regression in histology, and lower relapse rates than treatment with oral progesterone [57-59]. Lower rates of hysterectomy have also been reported after treatment with levonorgestrel IUDs [57-59].

Generally, relapses are frequent and occur in up to $50 \%$ of cases that undergo conservative treatment [60]. Standard conservative treatments should be followed-up by hysteroscopic examinations every third month and endometrial sampling [61]. In cases of recurrence a second cycle of progesterone treatment has been associated with response rates of up to $89 \%$ [62].

The combination of surgical resection and progesterone treatment has been associated with good oncologic and pregnancy outcomes in a small number of patients (Table 1) [63].

In women free of relapse, pregnancy should be achieved within the shortest period of time, and assisted reproductive treatments may have a place in reducing time to conception, thus reducing the time at risk of recurrence. Ovarian stimulation in cases of endometrial cancer has been an issue because of the supraphysiological estrogen levels attained during hormone treatments required for recovery of oocytes for IVF, and possible tumor stimulation. A few cases of successful live-births after IVF in women with previous endometrial cancer have been reported [64-71]. In these patients infertility treatment was not associated with an increased cancer recurrence rate [72].

The addition of letrozole to standard gonadotropin protocols has been proposed for ovarian stimulation among women with estrogen-sensitive tumors [73, 74]. The protocols, initially developed for women with breast cancer, could also be used in patients with endometrial cancers [75]. The performance of ovarian stimulation with a levonorgestrel IUD in situ has also been found to minimize the effect of estrogenic stimulation on the endometrium [76].

Whenever the desired family size has been reached, patients should undergo hysterectomy and bilateral 
salpingo-oophorectomy as a result of the persistent relapse risk [77].

A proportion of women treated for cancer might achieve pregnancy by surrogacy agreement, which is the carrying of a pregnancy by a third party (surrogate), a procedure that is allowed in some countries. Surrogacy gives the possibility of having biologically related children if gametes have been previously cryopreserved [76, 78].

As regards the QoL of women who have undergone fertility-sparing treatments in connection with early-stage endometrial cancer, the results of a meta-analysis indicated improved outcomes after treatment with levonorgestrel IUDs compared with oral progesterone, with reduced weight gain, sleep disorders, headaches, mood and libido disorders $[79,80]$.

\section{Ovarian cancer}

Ovarian cancers make up $2.6 \%$ of all female cancers. In 2015 around 21300 new cases of ovarian cancer were diagnosed in the US. The median age at diagnosis is 63 years, with $12 \%$ of patients under the age of 44 years $[1,2]$. The different approaches in fertility-sparing surgery in cases of ovarian cancer and borderline ovarian tumors are summarized in Table 2.

\section{Epithelial ovarian cancer}

Most cases of epithelial ovarian cancer are diagnosed at an advanced stage, making it the most lethal tumor of all gynecological malignancies. Standard treatment consists of bilateral salpingo-oophorectomy, hysterectomy, omentectomy as well as pelvic and para-aortic lymphadenectomy [81].

In women presenting with epithelial ovarian cancer diagnosed at an early stage (typically FIGO stage IA) who wish to preserve fertility, unilateral salpingo-oophorectomy together with appropriate staging, omentectomy, pelvic and para-aortic lymphadenectomy can be performed to preserve the uterus and one healthy ovary [82]. If the contralateral ovary appears macroscopically normal, most authors discourage sampling of it due to impairment of ovarian reserve and causation of additional adhesions by performing the biopsies [82]. In cases of epithelial ovarian cancer with bilateral ovarian involvement a conservative approach should not be applied [83].

Laparoscopic fertility-sparing surgery has been shown to be a feasible approach in cancers of FIGO stage IA and the 3-year survival rate is about $95 \%$ [84]. In patients presenting with a higher-risk early-stage ovarian cancer (IAG3 or higher) some authors have described fertilitysparing procedures in connection with non-impaired survival rates. However, the level of evidence regarding fertility-sparing surgery in high-risk ovarian cancer is limited due to the very small number of cases published [85]. In one study, if recurrence after fertility-sparing surgery occurred, long-term survival was $87 \%$ as regards ovarian and $48 \%$ as regards extra-ovarian relapse [82]. Data are still insufficient as regards other tumor types such as clear-cell carcinoma, but no differences in survival rates after fertility-sparing surgery have been reported in these patients when compared with women who have undergone radical surgery or fertility-sparing surgery in connection with non-clear-cell carcinoma [86]. Overall 5-year survival rates have been reported to be as high as $87 \%$, with approximately $12 \%$ of patients suffering cancer recurrence after fertility-sparing surgery, when combining both low- and high-risk cancers [17].

The use of platinum-based adjuvant chemotherapy has been proposed for patients with high-risk ovarian cancer (IAG2 or higher) as well as clear-cell carcinoma after fertility-sparing surgery $[85,87]$.

Some authors have suggested the addition of assisted reproductive techniques using gonadotropic ovarian stimulation for egg retrieval after the performance of fertilitysparing unilateral oophorectomy. These procedures are aimed at safeguarding fertility potential by cryopreservation of embryos or oocytes for the future. The patient, thereafter, may undergo adnexectomy of the remnant ovary in a subsequent operation [88]. Reduced ovarian reserve may be a concern in women with previous ovarian operations [89]. Up to now, data are lacking on ovarian cancer relapse rates after gonadotropic stimulation. However, data on women at high risk of ovarian cancer as a result of BRCA mutations are reassuring and no association between gonadotropic ovarian stimulation and ovarian cancer has been observed in these patients $[74,90]$.

Ovarian tissue cryopreservation in patients with early ovarian cancers or borderline tumors is highly controversial but has been described by some authors [32]. As autotransplantation of the retrieved ovarian tissue is not feasible due to the risk of reintroducing malignant cells, alternatives have been discussed, such as culture and maturation of oocytes gained from the tissue in vitro, a procedure still under development which could be used in the future [91].

As regards QoL, available data indicate no major differences in sexual satisfaction or sexual concerns in women who have undergone fertility-sparing surgery compared with women who have undergone radical surgery [46].

\section{Borderline ovarian tumors}

Borderline ovarian tumors (BOTs) comprise $10-20 \%$ of ovarian epithelial tumors [92]. In one study, among patients younger than 40 years, one third of ovarian cancer cases had borderline ovarian tumors [92]. Survival rates are about $99 \%$, with 70-month disease-free survival in cases of stage I tumors, and the survival rate in cases of stage III tumors is about $89 \%$ [3]. 
Table 2 Fertility-sparing interventions in women with borderline ovarian tumors or ovarian cancer

\begin{tabular}{|c|c|c|c|c|c|}
\hline Diagnosis & Type of Surgery & Description & Reproductive and Obstetric Outcomes & Oncologic Outcome & Quality of Life \\
\hline $\begin{array}{l}\text { Borderline Ovarian } \\
\text { Tumor FIGO Stage la }\end{array}$ & $\begin{array}{l}\text { Unilateral oophorectomy/ } \\
\text { bilateral cystectomy }\end{array}$ & $\begin{array}{l}\text { Removing the affected ovary } \\
\text { only, keeping in place the } \\
\text { unaffected one and the } \\
\text { uterus }\end{array}$ & $\begin{array}{l}\text { Spontaneous pregnancies have } \\
\text { been reported with favorable } \\
\text { obstetric outcome [99] }\end{array}$ & $\begin{array}{l}\text { Higher recurrence rates in fertility- } \\
\text { sparing surgery compared with } \\
\text { radical surgery, with no difference } \\
\text { in mortality [97, 98]. Recurrence } \\
0 \%-20 \% \text { versus } 12 \%-58 \% \\
\text { when only cystectomy was } \\
\text { performed [6] }\end{array}$ & $\begin{array}{l}\text { High quality of life and } \\
\text { higher sexual satisfaction } \\
\text { scores after fertility-sparing } \\
\text { surgery [103] }\end{array}$ \\
\hline $\begin{array}{l}\text { Borderline Ovarian } \\
\text { Tumor FIGO Stages } \\
\text { |c-II| }\end{array}$ & $\begin{array}{l}\text { Unilateral oophorectomy/ } \\
\text { bilateral cystectomy, peritoneal } \\
\text { staging, pelvic \& para-aortic } \\
\text { lymphadenectomy, omentectomy }\end{array}$ & $\begin{array}{l}\text { Removing the affected ovary } \\
\text { only, thorough oncological } \\
\text { staging }\end{array}$ & $\begin{array}{l}\text { Pregnancy rate of } 86 \% \text {, more } \\
\text { than half of the patients required } \\
\text { fertility treatment [99] }\end{array}$ & $\begin{array}{l}\text { No difference in recurrence } \\
\text { or survival compared with } \\
\text { radical surgery removing both } \\
\text { ovaries and the uterus }[6,99] \text {. }\end{array}$ & Lack of data \\
\hline $\begin{array}{l}\text { Ovarian Epithelial } \\
\text { Cancer FIGO Stage } \\
\text { IA, grade } 1\end{array}$ & $\begin{array}{l}\text { Unilateral oophorectomy, } \\
\text { peritoneal staging, pelvic \& } \\
\text { para-aortic lymphadenectomy } \\
\text { and omentectomy }\end{array}$ & $\begin{array}{l}\text { Removing the affected ovary } \\
\text { only, thorough oncological } \\
\text { staging }\end{array}$ & $\begin{array}{l}\text { Pregnancy rates of }>60 \% \\
\text { Pregnancies have been reported } \\
\text { with favorable obstetric outcome [145] }\end{array}$ & $\begin{array}{l}\text { 5-year survival } 87 \% \text {, recurrence } \\
7-12 \%[6,17]\end{array}$ & $\begin{array}{l}\text { No difference in quality of } \\
\text { life aspects or sexual satisfaction } \\
\text { scores compared with radical } \\
\text { surgery [46] }\end{array}$ \\
\hline $\begin{array}{l}\text { Ovarian Epithelial } \\
\text { Cancer - FIGO Stage } \\
\text { IA, grade 2-3 or } \\
\text { Clear Cell Carcinoma }\end{array}$ & $\begin{array}{l}\text { Unilateral oophorectomy, } \\
\text { peritoneal staging, pelvic \& } \\
\text { para-aortic lymphadenectomy, } \\
\text { omentectomy and adjuvant } \\
\text { chemotherapy }\end{array}$ & $\begin{array}{l}\text { Removing the affected ovary } \\
\text { only, thorough oncological } \\
\text { staging } \\
\text { Adjuvant platinum-based } \\
\text { chemotherapy }\end{array}$ & $\begin{array}{l}\text { Pregnancy rate of } 80 \% \text { with live-birth } \\
\text { rate of } 65 \% \text { in women presenting with } \\
\text { cancer grades } 1-3 . \text { Higher number of } \\
\text { women with cancer grades } 1-2 \\
\text { attempting pregnancy in comparison } \\
\text { with women with grade } 3 \text { cancers [87] }\end{array}$ & $\begin{array}{l}\text { No difference in recurrence or } \\
\text { survival compared with radical } \\
\text { surgery [86] }\end{array}$ & Lack of data \\
\hline $\begin{array}{l}\text { Malignant Germ Cell } \\
\text { Cancers grade I }\end{array}$ & $\begin{array}{l}\text { Unilateral oophorectomy, } \\
\text { peritoneal staging, } \\
\text { omentectomy, pelvic \& } \\
\text { para-aortic lymphadenectomy } \\
\text { and adjuvant chemotherapy }\end{array}$ & $\begin{array}{l}\text { Removing the affected ovary } \\
\text { only, adjuvant BEP } \\
\text { chemotherapy has been } \\
\text { recommended, or expectant } \\
\text { management }\end{array}$ & $\begin{array}{l}76 \% \text { pregnancy rate. Pregnancies have } \\
\text { been reported with favorable obstetric } \\
\text { outcome }[147,148]\end{array}$ & $\begin{array}{l}\text { Fertility-sparing surgery has not } \\
\text { been associated with impaired } \\
\text { oncological outcome [108] }\end{array}$ & $\begin{array}{l}\text { Good quality of life reported } \\
\text { with good psychological health } \\
\text { and sexual function [129] }\end{array}$ \\
\hline
\end{tabular}

Modified from: Rodriguez-Wallberg KA, Oktay K. Fertility preservation during cancer treatment: clinical guidelines. Cancer management and research. 2014;6:105-17

Abbreviations: FIGO International Federation of Gynecology and Obstetrics, BEP bleomycin, etoposide and cisplatin 
Because of relatively young age and good prognosis of the disease, conservative surgery can be performed in most BOT patients. Usually, adnexectomy on the affected side is performed, since cystectomy of the tumor has been associated with higher recurrence rates [3]. In case of bilateral BOTs, unilateral adnexectomy and contralateral cystectomy can be performed in women who wish to maintain reproductive potential. Even though fertility outcomes are uncertain, oncological prognoses similar to those of patients treated by means of radical surgery have been described [93, 94]. Surgical staging and histological subtypes (micropapillary and stromal micro-invasion) of BOTs have had no impact on recurrence [95]. Although associated with good prognosis overall, a higher level of lethal recurrence has been reported in cases of micopapillary serous BOT [96].

In general, conservative treatment of BOTs is associated with higher recurrence rates compared with radical treatment [3, 97]. However, after a follow-up period of seven years mortality has been reported to be very low and most authors regard conservative surgery as safe [98]. In a recent study on 59 patients concerning the role of fertility-sparing surgery in cases of advanced borderline tumors (FIGO stages IC-FIGO III) it was concluded that fertility-sparing surgery was not associated with relapse or mortality [99].

After conservative treatment of BOTs, patients should be counseled about the risk of diminished ovarian reserve following repeated conservative ovarian surgery or adnexectomy, and fertility counseling should be provided. Oocyte cryopreservation for future use can be an option for many of those women who do not have the intention to attempt pregnancy in the short term [89]. Due to the limited amount of data available it is not clear whether ovarian stimulation affects relapse time $[100,101]$. In in vitro models no detrimental stimulatory effects of FSH or estradiol (E2) were found in BOT cells [102].

After suffering BOTs patients report a good quality of life and good sexual function. Fertility-sparing surgery is not associated with a higher QoL, but patients after such surgery showed higher-level sexual activity than patients treated radically [103].

\section{Germ cell tumors}

Malignant ovarian germ cell tumors are rare $(3-5 \%$ of ovarian tumors), but are the most common ovarian tumors in very young women $(<20$ years of age $)[104,105]$.

The majority of patients with malignant ovarian germ cell tumors are diagnosed with stage 1 disease as a result of the rapidly growing character of this kind of tumor [105]. Overall survival rates in cases of germ cell tumors are encouraging and fertility-sparing surgery is not associated with worsening of outcome [106-108].
Ovarian germ cell tumors are relatively heterogeneous, and there is great variation in management. In cases of immature teratoma, 5-year survival rates at stages I and II have been described as being as high as $>93 \%$, with higher recurrence rates in cases of grade 2-3 tumors and advanced-stage tumors $[109,110]$. In yolk-sac tumors after fertility-sparing surgery and standard neoadjuvant chemotherapy 5-year survival has been found to be $>90 \%$ and a fertility-sparing approach has been suggested irrespective of cancer stage [111-113]. In pure dysgerminoma, 10-year disease-free survival was $>90 \%$, with overall survival around $100 \%[114,115]$. Due to this excellent long-term outcome, several authors suggest fertility-sparing treatment at all stages of ovarian dysgerminoma [116]. The usual treatment of ovarian germ cell tumors consists of unilateral adnexectomy, peritoneal staging and omentectomy [117]. However, some authors have described less invasive surgical procedures involving unilateral adnexectomy, cytology and peritoneal sampling in cases of dysgerminoma and immature teratoma limited to the ovary $[110,114]$. In yolk-sac tumors, however, complete staging has been associated with a favorable outcome as a result of different adjuvant treatment at advanced stages [111, 113].

Bilateral disease is uncommon in cases of germ cell tumors and if the contralateral ovary appears macroscopically normal no biopsy is advised owing to the risk of extra adhesions and impairment of ovarian reserve $[118,119]$. After fertility-sparing surgery, chemotherapy with bleomycin, etoposide and cisplatin (BEP) has been associated with improved disease-free survival [120]. However, recently a surveillance approach has been suggested for $50 \%$ of patients with early stage I tumors [121]. In cases of early-stage yolk-sac tumors (stage I) surgery patients (with chemotherapy limited only to cases of relapse) showed higher recurrence rates but no difference in overall survival, saving $77 \%$ of patients from chemotherapy [122]. However, in cases of higher-stage yolk-sac tumors standard-dose BEP chemotherapy has been associated with favorable overall survival rates and no apparent compromise of fertility rates [113, 123]. In early-stage pure dysgerminoma also, chemotherapy is only recommended in cases of relapse, according to several authors $[114,115]$. In patients with immature ovarian teratoma, stage I, grade $2-3$, adjuvant chemotherapy has been recommended by some authors, while the results of several studies suggest that an expectant approach with chemotherapy only in relapse situations in these patients may be more appropriate [124-126]. This is important because germ-cell cancer survivors treated with chemotherapy have shown relatively high chemotherapy-related secondary malignancy rates later in life [127]. Reproductive function, on the other hand, has been reported to be relatively good, with more than $80 \%$ of patients retaining 
reproductive function after chemotherapy and surgery $[116,119]$. IVF treatment in patients after germ-cell tumor therapy has been described in only a few cases [128].

Overall quality of life scores in germ-cell tumor survivors are good, with fertility preservation playing an important part [129].

\section{Reproductive outcomes after fertility-sparing surgery in cases of gynecological cancer}

Gestation in women treated for gynecological cancer may require specialized surveillance, in particular if the treatment has resulted in anatomic disturbance of the cervix or the uterus due to operative procedures or radiation therapy.

In one study, in cases of early-stage cervical cancer, after LLETZ resection no impairment of fertility was observed. However, depending on the depth of resection, patients showed a higher risk of preterm delivery (OR 1.7) and premature rupture of the membranes (OR 2.69), with no effect on neonatal outcome [130]. Many spontaneous conceptions have been reported after radical trachelectomy, with rates of over $80 \%$ when robot-assisted trachelectomy was performed [131]. Pregnancy rates of up to $60 \%$ have been reported after abdominal and vaginal trachelectomy [132, 133]. Interestingly, even after neoadjuvant chemotherapy and vaginal trachelectomy in cases of IB1 cancer, a pregnancy rate of $86 \%$ has been reported in women who attempted to conceive [134]. Performance of assisted reproductive techniques to achieve pregnancy has been reported to be necessary in up to $50 \%$ of cases [135].

In general, rates of pregnancy loss after trachelectomy are higher than in the general population [133]. As a result of amputation of the cervix, high risks of preterm delivery and premature rupture of the membranes have been described [136, 137]. Recent data indicate relatively favorable outcomes, with more than $90 \%$ of patients delivering in the third trimester [131]. However, the data are conflicting and whereas one study group reported $65 \%$ of infants prematurely born (<37 weeks) but only $4 \%$ at less than 32 weeks of gestation [44], a recent review reported $28 \%$ of premature children born before the 32nd week of gestation in a large population of $>300$ live-births after trachelectomy [17]. Routine performance of cerclage is still a matter of controversy, and cerclagerelated complications have been described [133, 138]. Several studies describe higher delivery rates achieved at term or during the third trimester after cerclage [139, $140]$. In any case, the risk of prematurity should be considered as well as access to a center with specialized neonatal care. Frequent vaginal ultrasonography should be performed to assess the risk of prematurity associated with shortness of the cervix, and fetal lung maturation should be induced when necessary [141].
As a result of postoperative scar tissue after trachelectomy, elective cesarean section after 37 weeks of gestation is recommended [136].

Pregnancies in women with previous endometrial cancer have been reported, with success rates of over $60 \%$ in women who attempted pregnancy [63, 72]. Pregnancy is achieved faster after treatments involving assisted reproductive techniques and miscarriage rates seem to be comparable to those in the general population [72, 142]. Overall, no adverse outcomes related to cancer treatment have been observed in over 75 live-births reported after endometrial cancer [17, 72].

In women with fertility-sparing surgery for ovarian cancer, use of assisted reproductive treatments involving IVF is indicated in many cases owing to a reduced ovarian reserve after repeated ovarian surgery or unilateral adnexectomy [143]. In series of cases reported, over $60 \%$ of women who actively attempted pregnancy conceived, and miscarriage rates were low $(<30 \%)[144,145]$. At present more than 220 pregnancies after ovarian cancer have been reported, with an overall miscarriage rate of $17 \%$ [17]. Similar data have been reported for women treated for BOTs [99]. Interestingly, adjuvant chemotherapy has not been associated with infertility, but young age at the time of chemotherapy has been associated with premature menopause later in life $[145,146]$. After fertility-sparing surgery in connection with germ-cell tumors, $76 \%$ of patients who sought pregnancy conceived naturally [147], and pregnancies in patients after fertility-sparing surgery and germ-cell tumor treatment did not show any complications [148].

International guidelines for fertility preservation have been published and access to fertility preservation for young female cancer patients encouraged, in particular by use of assisted reproductive methods globally available and regarded as clinical routines, such as cryopreservation of oocytes or embryos after emergency IVF [6, 30-33, 149]. As regards fertility-sparing surgery for fertility preservation among women with gynecological cancer, global utilization of the methods available is currently unknown. In a recent European study, data was collected from several countries, demonstrating a low incidence of fertilitypreserving surgery and it raised concerns as regards the need to centralize such treatments at accredited units, to ensure a sufficient number of patients at each center, with maintenance of good healthcare quality [150].

\section{Risk-reducing salpingo-oophorectomy in women at high risk of ovarian cancer who wish to preserve fertility}

Women who are carriers of BRCA1 mutations present with a 39-46 \% lifetime risk of developing ovarian cancer, and for carriers of BRCA2 mutations the lifetime risk is $12-20 \%$. The ovarian cancers that predominantly develop in BRCA1 and BRCA2 mutation-carriers are of 
serous or endometrioid histology and of high grade. In women with known BRCA mutations, periodic screening for ovarian cancer by way of assay of CA125 and transvaginal ultrasonography is recommended after the age of 3035 years, or 5-10 years before the youngest age at which ovarian cancer was first diagnosed in the family [151].

Risk-reducing salpingo-oophorectomy has been shown to reduce the risk of ovarian cancer by $85-90 \%$ and it should be offered to women with a BRCA mutation by age 40, or after the conclusion of childbearing [151].

Women who are carriers of BRCA mutations may have not yet built their families at the recommended age of riskreducing salpingo-oophorectomy, and some of them may wish to undergo procedures to preserve fertility. Data on fertility preservation for BRCA mutation-carriers are largely linked to their concomitant risk of breast cancer, and in that respect reports are reassuring, as the ovarian stimulation and IVF procedures required to cryopreserve embryos or oocytes have not been shown to negatively affect the risks of breast cancer or breast cancer relapse in reported patient series [74, 90, 152]. Although pregnancy appears to be safe for BRCA mutation-carriers after breast cancer, specific studies on women with BRCA mutations are lacking. Such women may elect to utilize preimplantation genetic diagnosis during IVF to avoid transmitting the mutation to their children, but this option may create additional psychological distress, and, therefore, thorough counseling and psychosocial evaluation are essential [153]. Additionally, it has been noted that carriers of BRCA mutations may have lower ovarian reserves and can experience earlier menopause than non-mutation carriers, and thus the reproductive span of BRCA carriers may be 2-4 years shorter than that in the general population $[74,154]$.

\section{Conclusions}

Current data on fertility-preservation options for women with early-stage gynecological cancer indicate oncological safety and high efficacy of fertility-sparing surgery. Some women presenting with sub-fertility may need to undergo assisted reproductive treatments to achieve pregnancy, which has not been shown to affect the oncologic outcome negatively. International guidelines for fertility preservation have been published and these underline the importance of timely discussion of the impact of cancer treatment on future fertility, and options for fertility preservation in all patients of reproductive age. The role of fertility-sparing treatment at more advanced stages of gynecological cancer has to be analyzed in further studies as a result of scarce data in this field.

\section{Abbreviations}

$\mathrm{BEP}$, bleomycin, etoposide and cisplatin; $\mathrm{BOT}$, borderline ovarian tumor; BRCA, breast cancer $1 / 2$ mutation; E2, estradiol; FSH, follicle-stimulating hormone; IUD, intrauterine device; IVF, in vitro fertilization; LLETZ, large loop excision of the transformation zone; OR, odds ratio; PCOS, polycystic ovary syndrome; QoL, quality of life

\section{Acknowledgements}

None.

\section{Funding}

This work has been supported by grants from The Swedish Society of Medicine, and Karolinska Institutet (KAR-W). Dr Rodriguez-Wallberg is supported by a

Clinical Investigator Grant from Stockholm County Council.

\section{Availability of data and materials}

Not applicable.

\section{Authors' contributions}

MF and KAR-W equally contributed to the writing and revision of the manuscript Both authors read and approved the final manuscript.

\section{Competing interests}

The authors declare that they have no competing interest.

Consent for publication

Not applicable.

Ethics approval and consent to participate

Not applicable.

\section{Author details}

'Department of Obstetrics and Gynecology, Division of Gynecological Endocrinology and Reproductive Medicine, Medical University of Vienna, Vienna, Austria. ${ }^{2}$ Wunschbaby Institut Feichtinger, Vienna, Austria.

${ }^{3}$ Department of Oncology - Pathology, Karolinska Institutet, Stockholm, Sweden. ${ }^{4}$ Department of Obstetrics and Gynecology, Section of Reproductive Medicine, Karolinska University Hospital, Novumhuset Plan 4, SE-141 86 Stockholm, Sweden.

Received: 12 May 2016 Accepted: 6 July 2016

Published online: 27 July 2016

\section{References}

1. Siegel RL, Miller KD, Jemal A. Cancer statistics, 2016. CA Cancer J Clin. 2016; 66:7-30.

2. Howlader N, Noone AM, Krapcho M, Garshell J, Miller D, Altekruse SF, Kosary CL, Yu M, Ruhl J, Tatalovich Z, Mariotto A, Lewis DR, Chen HS, Feuer EJ, Cronin KA (eds). SEER Cancer Statistics Review, 1975-2012, National Cancer Institute. Bethesda, MD, http://seer.cancer.gov/csr/1975_2012/, based on November 2014 SEER data submission, posted to the SEER web site, April 2015.

3. Zanetta G, Rota S, Chiari S, Bonazzi C, Bratina G, Mangioni C. Behavior of borderline tumors with particular interest to persistence, recurrence, and progression to invasive carcinoma: a prospective study. J Clin Oncol. 2001; 19:2658-64

4. Rosen A, Rodriquez-Wallberg KA, Rosenzweig L. Psychosocial distress in young cancer survivors. Semin Oncol Nurs. 2009;25:268-77.

5. Howard-Anderson J, Ganz PA, Bower JE, Stanton AL. Quality of life, fertility concerns, and behavioral health outcomes in younger breast cancer survivors: a systematic review. J Natl Cancer Inst. 2012:104:386-405.

6. Rodriguez-Wallberg KA, Oktay K. Fertility preservation during cancer treatment: clinical guidelines. Cancer Manag Res. 2014;6:105-17.

7. Rodriguez-Wallberg KA. Principles of cancer treatment: impact on reproduction. Adv Exp Med Biol. 2012:732:1-8.

8. Thibaud E, Rodriguez-Macias K, Trivin C, Esperou H, Michon J, Brauner R. Ovarian function after bone marrow transplantation during childhood. Bone Marrow Transplant. 1998:21:287-90.

9. Wallberg KA, Keros V, Hovatta O. Clinical aspects of fertility preservation in female patients. Pediatr Blood Cancer. 2009;53:254-60.

10. Wright JD, NathavithArana R, Lewin SN, Sun X, Deutsch I, Burke WM, et al. Fertility-conserving surgery for young women with stage IAI cervical cancer: safety and access. Obstet Gynecol. 2010;115:585-90. 
11. Spoozak L, Lewin SN, Burke WM, Deutsch I, Sun X, Herzog TJ, et al. Microinvasive adenocarcinoma of the cervix. Am J Obstet Gynecol. 2012;206:80:e1-6.

12. Marchiole $P$, Benchaib M, Buenerd A, Lazlo E, Dargent D, Mathevet $P$. Oncological safety of laparoscopic-assisted vaginal radical trachelectomy (LARVT or Dargent's operation): a comparative study with laparoscopic-assisted vaginal radical hysterectomy (LARVH). Gynecol Oncol. 2007;106:132-41.

13. Gien LT, Covens A. Fertility-sparing options for early stage cervical cancer. Gynecol Oncol. 2010;117:350-7.

14. Dargent DBJ, Remy I. Pregnancies following radical trachelectomy for invasive cervical concer. Society of Gynecologic Oncologists-Abstracts. Gynecol Oncol. 1994;52:105-8.

15. Helpman L, Grisaru D, Covens A. Early adenocarcinoma of the cervix: is radical vaginal trachelectomy safe? Gynecol Oncol. 2011;123:95-8.

16. $\mathrm{Xu} \mathrm{L}$, Sun FQ, Wang ZH. Radical trachelectomy versus radical hysterectomy for the treatment of early cervical cancer: a systematic review. Acta Obstet Gynecol Scand. 2011:90:1200-9.

17. Zapardiel I, Cruz M, Diestro MD, Requena A, Garcia-Velasco JA. Assisted reproductive techniques after fertility-sparing treatments in gynaecological cancers. Hum Reprod Update 2016 [Epub ahead of print].

18. Hoogendam JP, Zweemer RP, Hobbelink MG, van den Bosch MA, Verheijen $\mathrm{RH}$, Veldhuis WB. 99mTc-Nanocolloid SPECT/MRI Fusion for the Selective Assessment of Nonenlarged Sentinel Lymph Nodes in Patients with EarlyStage Cervical Cancer. J Nucl Med. 2016;57:551-6.

19. Shepherd JH, Spencer C, Herod J, Ind TE. Radical vaginal trachelectomy as a fertility-sparing procedure in women with early-stage cervical cancer-cumulative pregnancy rate in a series of 123 women. BJOG. 2006;113:719-24.

20. Fagotti A, Gagliardi ML, Moruzzi C, Carone V, Scambia G, Fanfani F. Excisional cone as fertility-sparing treatment in early-stage cervical cancer. Fertil Steril. 2011;95:1109-12.

21. Maneo A, Sideri M, Scambia G, Boveri S, Dell'anna T, Villa M, et al. Simple conization and lymphadenectomy for the conservative treatment of stage IB1 cervical cancer. An Italian experience. Gynecol Oncol. 2011;123:557-60.

22. Plante M, Lau S, Brydon L, Swenerton K, LeBlanc R, Roy M. Neoadjuvant chemotherapy followed by vaginal radical trachelectomy in bulky stage IB1 cervical cancer: case report. Gynecol Oncol. 2006;101:367-70.

23. Robova H, Halaska MJ, Pluta M, Skapa P, Matecha J, Lisy J, et al. Oncological and pregnancy outcomes after high-dose density neoadjuvant chemotherapy and fertility-sparing surgery in cervical cancer. Gynecol Oncol. 2014;135:213-6.

24. Pareja R, Rendon GJ, Vasquez M, Echeverri L, Sanz-Lomana CM, Ramirez PT. Immediate radical trachelectomy versus neoadjuvant chemotherapy followed by conservative surgery for patients with stage IB1 cervical cancer with tumors $2 \mathrm{~cm}$ or larger: A literature review and analysis of oncological and obstetrical outcomes. Gynecol Oncol. 2015;137:574-80.

25. Morice P, Castaigne D, Haie-Meder C, Pautier P, El Hassan J, Duvillard P, et al. Laparoscopic ovarian transposition for pelvic malignancies: indications and functional outcomes. Fertil Steril. 1998;70:956-60.

26. Morice P, Juncker L, Rey A, El-Hassan J, Haie-Meder C, Castaigne D. Ovarian transposition for patients with cervical carcinoma treated by radiosurgical combination. Fertil Steril. 2000;74:743-8.

27. Ghadjar P, Budach V, Kohler C, Jantke A, Marnitz S. Modern radiation therapy and potential fertility preservation strategies in patients with cervical cancer undergoing chemoradiation. Radiat Oncol. 2015;10:50.

28. Feeney DD, Moore DH, Look KY, Stehman FB, Sutton GP. The fate of the ovaries after radical hysterectomy and ovarian transposition. Gynecol Oncol. 1995;56:3-7

29. Wo JY, Viswanathan AN. Impact of radiotherapy on fertility, pregnancy, and neonatal outcomes in female cancer patients. Int J Radiat Oncol Biol Phys. 2009;73:1304-12

30. von Wolff M, Thaler CJ, Frambach T, Zeeb C, Lawrenz B, Popovici RM, et al. Ovarian stimulation to cryopreserve fertilized oocytes in cancer patients can be started in the luteal phase. Fertil Steril. 2009:92:1360-5.

31. Bedoschi G, Oktay K. Current approach to fertility preservation by embryo cryopreservation. Fertil Steril. 2013;99:1496-502.

32. Donnez J, Dolmans MM. Fertility preservation in women. Nat Rev Endocrinol. 2013;9:735-49.

33. Garcia-Velasco JA, Domingo J, Cobo A, Martinez M, Carmona L, Pellicer A. Five years' experience using oocyte vitrification to preserve fertility for medical and nonmedical indications. Fertil Steril. 2013;99:1994-9.
34. Dahhan T, Dancet EA, Miedema DV, van der Veen F, Goddijn M. Reproductive choices and outcomes after freezing oocytes for medical reasons: a follow-up study. Hum Reprod. 2014;29:1925-30.

35. Rodriguez-Wallberg KA, Karlstrom PO, Rezapour M, Castellanos E, Hreinsson J, Rasmussen C, et al. Full-term newborn after repeated ovarian tissue transplants in a patient treated for Ewing sarcoma by sterilizing pelvic irradiation and chemotherapy. Acta Obstet Gynecol Scand. 2015;94:324-8.

36. Green DM, Sklar CA, Boice Jr JD, Mulvihill JJ, Whitton JA, Stovall M, et al. Ovarian failure and reproductive outcomes after childhood cancer treatment: results from the Childhood Cancer Survivor Study. J Clin Oncol. 2009;27:2374-81.

37. Kim SS, Lee WS, Chung MK, Lee HC, Lee HH, Hill D. Long-term ovarian function and fertility after heterotopic autotransplantation of cryobanked human ovarian tissue: 8-year experience in cancer patients. Fertil Steril. 2009:91:2349-54.

38. Donnez J, Dolmans MM, Pellicer A, Diaz-Garcia C, Sanchez Serrano M, Schmidt KT, et al. Restoration of ovarian activity and pregnancy after transplantation of cryopreserved ovarian tissue: a review of 60 cases of reimplantation. Fertil Steril. 2013;99:1503-13.

39. Rodriguez-Wallberg KA, Tanbo T, Tinkanen H, Thurin-Kjellberg A, Nedstrand $E$, et al. Current practice and clinical achievements in cryopreservation of ovarian tissue for fertility preservation in the Nordic Countries - Compilation of 20 years of multicentre experience. Acta Obstetricia et Gynecologica Scandinavica 2016, in press.

40. Donnez J, Dolmans MM. Ovarian cortex transplantation: 60 reported live births brings the success and worldwide expansion of the technique towards routine clinical practice. J Assist Reprod Genet. 2015;32:1167-70.

41. Nakanishi T, Wakai $K$, Ishikawa H, Nawa A, Suzuki Y, Nakamura S, et al. A comparison of ovarian metastasis between squamous cell carcinoma and adenocarcinoma of the uterine cervix. Gynecol Oncol. 2001;82:504-9.

42. Brannstrom M, Johannesson L, Bokstrom H, Kvarnstrom N, Molne J, DahmKahler P, et al. Livebirth after uterus transplantation. Lancet. 2015;385:607-16.

43. Pondrom S. US to Offer Uterus Transplants. Am J Transplant. 2016;16:375-6.

44. Plante M, Gregoire J, Renaud MC, Roy M. The vaginal radical trachelectomy: an update of a series of 125 cases and 106 pregnancies. Gynecol Oncol. 2011:121:290-7.

45. Aust T, Herod J, Macdonald R, Gazvani R. Infertility after fertility-preserving surgery for cervical carcinoma: the next challenge for reproductive medicine? Hum Fertil (Camb). 2007;10:21-4.

46. Chan JL, Letourneau J, Salem W, Cil AP, Chan SW, Chen LM, et al. Sexual satisfaction and quality of life in survivors of localized cervical and ovarian cancers following fertility-sparing surgery. Gynecol Oncol. 2015;139:141-7.

47. Froeding LP, Ottosen C, Rung-Hansen H, Svane D, Mosgaard BJ, Jensen PT. Sexual functioning and vaginal changes after radical vaginal trachelectomy in early stage cervical cancer patients: a longitudinal study. J Sex Med. 2014;11:595-604.

48. Froding LP, Ottosen C, Mosgaard BJ, Jensen PT. Quality of life, urogynecological morbidity, and lymphedema after radical vaginal trachelectomy for early-stage cervical cancer. Int J Gynecol Cancer. 2015;25:699-706.

49. Fanfani F, Landoni F, Gagliardi ML, Fagotti A, Preti E, Moruzzi MC, et al. Sexual and Reproductive Outcomes in Early Stage Cervical Cancer Patients after Excisional Cone as a Fertility-sparing Surgery: An Italian Experience. J Reprod infertility. 2014;15:29-34.

50. Haoula Z, Salman M, Atiomo W. Evaluating the association between endometrial cancer and polycystic ovary syndrome. Hum Reprod. 2012;27:1327-31.

51. Amant $F$, Moerman $P$, Neven $P$, Timmerman $D$, Van Limbergen $E$, Vergote I. Endometrial cancer. Lancet. 2005;366:491-505.

52. Ben-Shachar I, Vitellas KM, Cohn DE. The role of MRI in the conservative management of endometrial cancer. Gynecol Oncol. 2004;93:233-7.

53. Kim MK, Seong SJ, Kim YS, Song T, Kim ML, Yoon BS, et al. Combined medroxyprogesterone acetate/levonorgestrel-intrauterine system treatment in young women with early-stage endometrial cancer. Am J Obstet Gynecol. 2013;209:358. e1-4.

54. Minig L, Franchi D, Boveri S, Casadio C, Bocciolone L, Sideri M. Progestin intrauterine device and $\mathrm{GnRH}$ analogue for uterus-sparing treatment of endometrial precancers and well-differentiated early endometrial carcinoma in young women. Ann Oncol. 2011:22:643-9.

55. Baker J, Obermair A, Gebski V, Janda M. Efficacy of oral or intrauterine device-delivered progestin in patients with complex endometrial hyperplasia with atypia or early endometrial adenocarcinoma: a metaanalysis and systematic review of the literature. Gynecol Oncol. 2012; 125:263-70. 
56. Hubbs JL, Saig RM, Abaid LN, Bae-Jump VL, Gehrig PA. Systemic and local hormone therapy for endometrial hyperplasia and early adenocarcinoma. Obstet Gynecol. 2013;121:1172-80.

57. Gallos ID, Krishan P, Shehmar M, Ganesan R, Gupta JK. LNG-IUS versus oral progestogen treatment for endometrial hyperplasia: a long-term comparative cohort study. Hum Reprod. 2013;28:2966-71.

58. Gallos ID, Krishan P, Shehmar M, Ganesan R, Gupta JK. Relapse of endometrial hyperplasia after conservative treatment: a cohort study with long-term follow-up. Hum Reprod. 2013;28:1231-6.

59. Abu Hashim H, Ghayaty E, El Rakhawy M. Levonorgestrel-releasing intrauterine system vs oral progestins for non-atypical endometrial hyperplasia: a systematic review and metaanalysis of randomized trials. Am J Obstet Gynecol. 2015;213: 469-78.

60. Ushijima K, Yahata H, Yoshikawa H, Konishi I, Yasugi T, Saito T, et al. Multicenter phase II study of fertility-sparing treatment with medroxyprogesterone acetate for endometrial carcinoma and atypical hyperplasia in young women. J Clin Oncol. 2007;25:2798-803.

61. Gunderson CC, Fader AN, Carson KA, Bristow RE. Oncologic and reproductive outcomes with progestin therapy in women with endometrial hyperplasia and grade 1 adenocarcinoma: a systematic review. Gynecol Oncol. 2012;125:477-82.

62. Park JY, Lee SH, Seong SJ, Kim DY, Kim TJ, Kim JW, et al. Progestin retreatment in patients with recurrent endometrial adenocarcinoma after successful fertility-sparing management using progestin. Gynecol Oncol. 2013:129:7-11.

63. Mazzon I, Corrado G, Masciullo V, Morricone D, Ferrandina G, Scambia G. Conservative surgical management of stage IA endometrial carcinoma for fertility preservation. Fertil Steril. 2010;93:1286-9.

64. Paulson RJ, Sauer MV, Lobo RA. Pregnancy after in vitro fertilization in a patient with stage I endometrial carcinoma treated with progestins. Fertil Steril. 1990;54:735-6.

65. Sardi J, Anchezar Henry JP, Paniceres G, Gomez Rueda N, Vighi S. Primary hormonal treatment for early endometrial carcinoma. Eur J Gynaecol Oncol. 1998;19:565-8

66. Shibahara H, Shigeta M, Toji H, Wakimoto E, Adachi S, Ogasawara T, et al. Successful pregnancy in an infertile patient with conservatively treated endometrial adenocarcinoma after transfer of embryos obtained by intracytoplasmic sperm injection. Hum Reprod. 1999;14:1908-11.

67. Ogawa S, Koike T, Shibahara H, Ohwada M, Suzuki M, Araki S, et al. Assisted reproductive technologies in conjunction with conservatively treated endometrial adenocarcinoma. A case report. Gynecol Obstet Investig. 2001:51:214-6.

68. Pinto AB, Gopal M, Herzog TJ, Pfeifer JD, Williams DB. Successful in vitro fertilization pregnancy after conservative management of endometrial cancer. Fertil Steril. 2001;76:826-9.

69. Lowe MP, Cooper BC, Sood AK, Davis WA, Syrop CH, Sorosky Jl. Implementation of assisted reproductive technologies following conservative management of FIGO grade I endometrial adenocarcinoma and/or complex hyperplasia with atypia. Gynecol Oncol. 2003:91:569-72.

70. Nakao Y, Nomiyama M, Kojima K, Matsumoto Y, Yamasaki F, Iwasaka T. Successful pregnancies in 2 infertile patients with endometrial adenocarcinoma. Gynecol Obstet Investig. 2004;58:68-71.

71. Yarali H, Bozdag G, Aksu T, Ayhan A. A successful pregnancy after intracytoplasmic sperm injection and embryo transfer in a patient with endometrial cancer who was treated conservatively. Fertil Steril. 2004;81: 214-6.

72. Park JY, Seong SJ, Kim TJ, Kim JW, Kim SM, Bae DS, et al. Pregnancy outcomes after fertility-sparing management in young women with early endometrial cancer. Obstet Gynecol. 2013;121:136-42.

73. Oktay K, Turkcuoglu I, Rodriguez-Wallberg KA. GnRH agonist trigger for women with breast cancer undergoing fertility preservation by aromatase inhibitor/FSH stimulation. Reprod Biomed Online. 2010;20:783-8.

74. Rodriguez-Wallberg KA, Oktay K. Fertility preservation and pregnancy in women with and without BRCA mutation-positive breast cancer. Oncologist. 2012;17:1409-17

75. Azim A, Oktay K. Letrozole for ovulation induction and fertility preservation by embryo cryopreservation in young women with endometrial carcinoma. Fertil Steril. 2007;88:657-64.

76. Juretzka MM, O'Hanlan KA, Katz SL, El-Danasouri I, Westphal LM. Embryo cryopreservation after diagnosis of stage IIB endometrial cancer and subsequent pregnancy in a gestational carrier. Fertil Steril. 2005;83:1041.
77. Niwa K, Tagami K, Lian Z, Onogi K, Mori H, Tamaya T. Outcome of fertilitypreserving treatment in young women with endometrial carcinomas. BJOG. 2005;112:317-20.

78. Lavery S, Ng C, Kyrgiou M, Farthing A. Gestational surrogacy after intraoperative oocyte collection in a hysterectomised woman diagnosed with endometrial cancer. BJOG. 2011;118:1669-71.

79. Gallos ID, Shehmar M, Thangaratinam S, Papapostolou TK, Coomarasamy A, Gupta JK. Oral progestogens vs levonorgestrel-releasing intrauterine system for endometrial hyperplasia: a systematic review and metaanalysis. Am J Obstet Gynecol. 2010;203:547. e1-10.

80. Tomao F, Peccatori F, Pup LD, Franchi D, Zanagnolo V, Panici PB, et al. Special issues in fertility preservation for gynecologic malignancies. Crit Rev Oncol Hematol. 2016;97:206-19.

81. Redman C, Duffy S, Bromham N, Francis K, Guideline Development G. Recognition and initial management of ovarian cancer: summary of NICE guidance. BMJ. 2011;342:d2073.

82. Bentivegna E, Fruscio R, Roussin S, Ceppi L, Satoh T, Kajiyama $H$, et al. Long-term follow-up of patients with an isolated ovarian recurrence after conservative treatment of epithelial ovarian cancer: review of the results of an international multicenter study comprising 545 patients. Fertil Steril. 2015:104:1319-24.

83. Morice P, Leblanc E, Rey A, Baron M, Querleu D, Blanchot J, et al. Conservative treatment in epithelial ovarian cancer: results of a multicentre study of the GCCLCC (Groupe des Chirurgiens de Centre de Lutte Contre le Cancer) and SFOG (Societe Francaise d'Oncologie Gynecologique). Hum Reprod. 2005;20: 1379-85.

84. Ghezzi F, Cromi A, Fanfani F, Malzoni M, Ditto A, Pierandrea I, et al. Laparoscopic fertility-sparing surgery for early ovarian epithelial cancer: a multi-institutional experience. Gynecol Oncol. 2016. Epub ahead of print.

85. Ditto A, Martinelli F, Bogani G, Lorusso D, Carcangiu M, Chiappa V, et al. Long-term safety of fertility sparing surgery in early stage ovarian cancer: comparison to standard radical surgical procedures. Gynecol Oncol. 2015; 138:78-82.

86. Kajiyama H, Shibata K, Mizuno M, Hosono S, Kawai M, Nagasaka T, et al. Fertility-sparing surgery in patients with clear-cell carcinoma of the ovary: is it possible? Hum Reprod. 2011;26:3297-302.

87. Fruscio R, Corso S, Ceppi L, Garavaglia D, Garbi A, Floriani I, et al. Conservative management of early-stage epithelial ovarian cancer: results of a large retrospective series. Ann Oncol. 2013;24:138-44.

88. Alvarez M, Sole M, Devesa M, Fabregas R, Boada M, Tur R, et al. Live birth using vitrified-warmed oocytes in invasive ovarian cancer: case report and literature review. Reprod Biomed Online. 2014;28:663-8.

89. Druckenmiller S, Goldman KN, Labella PA, Fino ME, Bazzocchi A, Noyes N. Successful Oocyte Cryopreservation in Reproductive-Aged Cancer Survivors. Obstet Gynecol. 2016:127:474-80.

90. Perri T, Lifshitz D, Sadetzki S, Oberman B, Meirow D, Ben-Baruch G, et al Fertility treatments and invasive epithelial ovarian cancer risk in Jewish Israeli BRCA1 or BRCA2 mutation carriers. Fertil Steril. 2015;103:1305-12.

91. Abir R, Ben-Aharon I, Garor R, Yaniv I, Ash S, Stemmer SM, et al. Cryopreservation of in vitro matured oocytes in addition to ovarian tissue freezing for fertility preservation in paediatric female cancer patients before and after cancer therapy. Hum Reprod. 2016;31:750-62.

92. Skirnisdottir I, Garmo H, Wilander E, Holmberg L. Borderline ovarian tumors in Sweden 1960-2005: trends in incidence and age at diagnosis compared to ovarian cancer. Int J Cancer. 2008;123:1897-901.

93. Faluyi O, Mackean M, Gourley C, Bryant A, Dickinson HO. Interventions for the treatment of borderline ovarian tumours. Cochrane Database Syst Rev. 2010;(9). Art. No.: CD007696. doi:10.1002/14651858.CD007696.pub2.

94. Vasconcelos I, de Sousa Mendes M. Conservative surgery in ovarian borderline tumours: a meta-analysis with emphasis on recurrence risk. Eur J Cancer. 2015; 51:620-31.

95. Uzan C, Muller E, Kane A, Rey A, Gouy S, Bendiffallah S, et al. Prognostic factors for recurrence after conservative treatment in a series of 119 patients with stage I serous borderline tumors of the ovary. Ann Oncol. 2014;25:166-71.

96. Vasconcelos I, Darb-Esfahani S, Sehouli J. Serous and mucinous borderline ovarian tumours: differences in clinical presentation, high-risk histopathological features, and lethal recurrence rates. BJOG. 2016:123:498-508.

97. Fauvet R, Boccara J, Dufournet C, David-Montefiore E, Poncelet C, Darai E. Restaging surgery for women with borderline ovarian tumors: results of a French multicenter study. Cancer. 2004;100:1145-51. 
98. Suh-Burgmann E. Long-term outcomes following conservative surgery for borderline tumor of the ovary: a large population-based study. Gynecol Oncol. 2006;103:841-7.

99. Helpman L, Beiner ME, Aviel-Ronen S, Perri T, Hogen L, Jakobson-Setton A et al. Safety of ovarian conservation and fertility preservation in advanced borderline ovarian tumors. Fertil Steril. 2015;104:138-44.

100. Denschlag D, von Wolff M, Amant F, Kesic V, Reed N, Schneider A, et al. Clinical recommendation on fertility preservation in borderline ovarian neoplasm: ovarian stimulation and oocyte retrieval after conservative surgery. Gynecol Obstet Investig. 2010;70:160-5.

101. Darai E, Fauvet R, Uzan C, Gouy S, Duvillard P, Morice P. Fertility and borderline ovarian tumor: a systematic review of conservative management, risk of recurrence and alternative options. Hum Reprod Update. 2013;19:151-66.

102. Basille C, Olivennes F, Le Calvez J, Beron-Gaillard N, Meduri G, Lhomme C, et al. Impact of gonadotrophins and steroid hormones on tumour cells derived from borderline ovarian tumours. Hum Reprod. 2006;21:3241-5.

103. Farthmann J, Hasenburg A, Weil M, Fotopoulou C, Ewald-Riegler N, du Bois $\mathrm{O}$, et al. Quality of life and sexual function in patients with borderline tumors of the ovary. A substudy of the Arbeitsgemeinschaft Gynaekologische Onkologie (AGO) study group ROBOT study. Support Care Cancer. 2015;23:117-23.

104. Quirk JT, Natarajan N, Mettlin CJ. Age-specific ovarian cancer incidence rate patterns in the United States. Gynecol Oncol. 2005;99:248-50.

105. Smith HO, Berwick M, Verschraegen CF, Wiggins C, Lansing L, Muller CY, et al. Incidence and survival rates for female malignant germ cell tumors. Obstet Gynecol. 2006;107:1075-85.

106. Chan JK, Tewari KS, Waller S, Cheung MK, Shin JY, Osann K, et al. The influence of conservative surgical practices for malignant ovarian germ cell tumors. J Surg Oncol. 2008;98:111-6.

107. Mangili G, Sigismondi C, Gadducci A, Cormio G, Scollo P, Tateo S, et al. Outcome and risk factors for recurrence in malignant ovarian germ cell tumors: a MITO-9 retrospective study. Int J Gynecol Cancer. 2011;21:1414-21.

108. Park JY, Kim DY, Suh DS, Kim JH, Kim YM, Kim YT, et al. Outcomes of pediatric and adolescent girls with malignant ovarian germ cell tumors. Gynecol Oncol. 2015;137:418-22.

109. Weinberg LE, Lurain JR, Singh DK, Schink JC. Survival and reproductive outcomes in women treated for malignant ovarian germ cell tumors. Gynecol Oncol. 2011;121:285-9.

110. Jorge S, Jones NL, Chen L, Hou JY, Tergas Al, Burke WM et al. Characteristics, treatment and outcomes of women with immature ovarian Teratoma, 19982012. Gynecologic oncology 2016 [Epub ahead of print].

111. Nawa A, Obata N, Kikkawa F, Kawai M, Nagasaka T, Goto S, et al. Prognostic factors of patients with yolk sac tumors of the ovary. Am J Obstet Gynecol. 2001;184:1182-8.

112. Kang H, Kim TJ, Kim WY, Choi CH, Lee JW, Kim BG, et al. Outcome and reproductive function after cumulative high-dose combination chemotherapy with bleomycin, etoposide and cisplatin (BEP) for patients with ovarian endodermal sinus tumor. Gynecol Oncol. 2008;111:106-10.

113. de La Motte RT, Pautier P, Duvillard P, Rey A, Morice P, Haie-Meder C, et al. Survival and reproductive function of 52 women treated with surgery and bleomycin, etoposide, cisplatin (BEP) chemotherapy for ovarian yolk sac tumor. AnnOncol. 2008;19:1435-41.

114. Vicus D, Beiner ME, Klachook S, Le LW, Laframboise S, Mackay H. Pure dysgerminoma of the ovary 35 years on: a single institutional experience. Gynecol Oncol. 2010;117:23-6.

115. Mangili G, Sigismondi C, Lorusso D, Cormio G, Scollo P, Vigano R, et al. Is surgical restaging indicated in apparent stage IA pure ovarian dysgerminoma? The MITO group retrospective experience. Gynecol Oncol. 2011;121:280-4.

116. Brewer M, Gershenson DM, Herzog CE, Mitchell MF, Silva EG, Wharton JT. Outcome and reproductive function after chemotherapy for ovarian dysgerminoma. J Clin Oncol. 1999;17:2670-5.

117. Pectasides D, Pectasides E, Kassanos D. Germ cell tumors of the ovary. Cancer Treat Rev. 2008:34:427-41

118. Kurman RJ, Norris HJ. Malignant germ cell tumors of the ovary. Hum Pathol. 1977:8:551-64.

119. Gershenson DM. Management of ovarian germ cell tumors. J Clin Oncol. 2007;25:2938-43

120. Cushing B, Giller R, Cullen JW, Marina NM, Lauer SJ, Olson TA, et al. Randomized comparison of combination chemotherapy with etoposide, bleomycin, and either high-dose or standard-dose cisplatin in children and adolescents with high-risk malignant germ cell tumors: a pediatric intergroup study-Pediatric Oncology Group 9049 and Children's Cancer Group 8882. J Clin Oncol. 2004;22:2691-700.

121. Billmire DF, Cullen JW, Rescorla FJ, Davis M, Schlatter MG, Olson TA, et al. Surveillance after initial surgery for pediatric and adolescent girls with stage I ovarian germ cell tumors: report from the Children's Oncology Group. J Clin Oncol. 2014;32:465-70.

122. Park JY, Kim DY, Suh DS, Kim JH, Kim YM, Kim YT, et al. Outcomes of surgery alone and surveillance strategy in young women with stage I malignant ovarian germ cell tumors. Int J Gynecol Cancer. 2016;26:859-64.

123. Satoh T, Aoki Y, Kasamatsu T, Ochiai K, Takano M, Watanabe $Y$, et al. Administration of standard-dose BEP regimen (bleomycin + etoposide + cisplatin) is essential for treatment of ovarian yolk sac tumour. Eur J Cancer. 2015;51:340-51.

124. Cushing B, Giller R, Ablin A, Cohen L, Cullen J, Hawkins E, et al. Surgical resection alone is effective treatment for ovarian immature teratoma in children and adolescents: a report of the pediatric oncology group and the children's cancer group. Am J Obstet Gynecol. 1999;181:353-8.

125. Mangili G, Scarfone G, Gadducci A, Sigismondi C, Ferrandina G, Scibilia G, et al. Is adjuvant chemotherapy indicated in stage I pure immature ovarian teratoma (IT)? A multicentre Italian trial in ovarian cancer (MITO-9). Gynecol Oncol. 2010;119:48-52

126. Vicus D, Beiner ME, Clarke B, Klachook S, Le LW, Laframboise S, et al. Ovarian immature teratoma: treatment and outcome in a single institutional cohort. Gynecol Oncol. 2011;123:50-3.

127. Travis LB, Beard C, Allan JM, Dahl AA, Feldman DR, Oldenburg J, et al. Testicular cancer survivorship: research strategies and recommendations. J Natl Cancer Inst. 2010;102:1114-30.

128. Kitajima Y, Endo T, Hayashi T, Ishioka S, Baba T, Honnma H, et al. A successful IVF-pregnancy in a patient who underwent conservative surgery followed by a regimen of cisplatin, vinblastine and peplomycin to treat an advanced ovarian mixed germ cell tumour: a case report. Hum Reprod. 2007;22:850-2.

129. Champion V, Williams SD, Miller A, Reuille KM, Wagler-Ziner K, Monahan PO, et al. Quality of life in long-term survivors of ovarian germ cell tumors: a Gynecologic Oncology Group study. Gynecol Oncol. 2007;105:687-94.

130. Kyrgiou M, Koliopoulos G, Martin-Hirsch P, Arbyn M, Prendiville W, Paraskevaidis E. Obstetric outcomes after conservative treatment for intraepithelial or early invasive cervical lesions: systematic review and metaanalysis. Lancet. 2006;367:489-98.

131. Johansen $G$, Lonnerfors $C$, Falconer $H$, Persson J. Reproductive and oncologic outcome following robot-assisted laparoscopic radical trachelectomy for early stage cervical cancer. Gynecol Oncol. 2016;141:160-5.

132. Beiner ME, Covens A. Surgery insight: radical vaginal trachelectomy as a method of fertility preservation for cervical cancer. Nat Clin Pract Oncol. 2007:4:353-61.

133. Pareja R, Rendon GJ, Sanz-Lomana CM, Monzon O, Ramirez PT. Surgical, oncological, and obstetrical outcomes after abdominal radical trachelectomy a systematic literature review. Gynecol Oncol. 2013;131:77-82.

134. Yan H, Liu Z, Fu X, Li Y, Che H, Mo R, et al. Long-term outcomes of radical vaginal trachelectomy and laparoscopic pelvic lymphadenectomy after neoadjuvant chemotherapy for the IB1 cervical cancer: A series of 60 cases. Int J Surg. 2016;29:38-42.

135. Hauerberg L, Hogdall C, Loft A, Ottosen C, Bjoern SF, Mosgaard BJ, et al. Vaginal radical trachelectomy for early stage cervical cancer. Results of the Danish National Single Center Strategy. Gynecol Oncol. 2015;138: 304-10.

136. Ebisawa K, Takano M, Fukuda M, Fujiwara K, Hada T, Ota Y, et al. Obstetric outcomes of patients undergoing total laparoscopic radical trachelectomy for early stage cervical cancer. Gynecol Oncol. 2013;131:83-6.

137. Park JY, Kim DY, Suh DS, Kim JH, Kim YM, Kim YT, et al. Reproductive outcomes after laparoscopic radical trachelectomy for early-stage cervical cancer. J Gynecol Oncol. 2014;25:9-13.

138. Olawaiye A, Del Carmen M, Tambouret R, Goodman A, Fuller A, Duska LR. Abdominal radical trachelectomy: Success and pitfalls in a general gynecologic oncology practice. Gynecol Oncol. 2009;112:506-10.

139. Jolley JA, Battista L, Wing DA. Management of pregnancy after radical trachelectomy: case reports and systematic review of the literature. Am J Perinatol. 2007:24:531-9.

140. Kim CH, Abu-Rustum NR, Chi DS, Gardner GJ, Leitao Jr MM, Carter J, et al. Reproductive outcomes of patients undergoing radical trachelectomy for early-stage cervical cancer. Gynecol Oncol. 2012;125:585-8. 
141. Pils S, Eppel W, Seemann R, Natter C, Ott J. Sequential cervical length screening in pregnancies after loop excision of the transformation zone conisation: a retrospective analysis. BJOG. 2014;121:457-62.

142. Gallos ID, Yap J, Rajkhowa M, Luesley DM, Coomarasamy A, Gupta JK. Regression, relapse, and live birth rates with fertility-sparing therapy for endometrial cancer and atypical complex endometrial hyperplasia: a systematic review and metaanalysis. Am J Obstet Gynecol. 2012;207:266:e1-12.

143. Park JY, Heo EJ, Lee JW, Lee YY, Kim TJ, Kim BG, et al. Outcomes of laparoscopic fertility-sparing surgery in clinically early-stage epithelial ovarian cancer. J Gynecol Oncol. 2016;27:e20.

144. Fotopoulou C, Braicu I, Sehouli J. Fertility-sparing surgery in early epithelial ovarian cancer: a viable option? Obstet Gynecol Int. 2012;2012:238061.

145. Zapardiel I, Diestro MD, Aletti G. Conservative treatment of early stage ovarian cancer: oncological and fertility outcomes. Eur J Surg Oncol. 2014; 40:387-93.

146. Letourneau J, Chan J, Salem W, Chan SW, Shah M, Ebbel E, et al. Fertility sparing surgery for localized ovarian cancers maintains an ability to conceive, but is Associated with diminished reproductive potential. J Surg Oncol. 2015;112:26-30.

147. Ertas IE, Taskin S, Goklu R, Bilgin M, Goc G, Yildirim Y, et al. Long-term oncological and reproductive outcomes of fertility-sparing cytoreductive surgery in females aged 25 years and younger with malignant ovarian germ cell tumors. J Obstet Gynaecol Res. 2014;40:797-805.

148. Boran N, Tulunay G, Caliskan E, Kose MF, Haberal A. Pregnancy outcomes and menstrual function after fertility sparing surgery for pure ovarian dysgerminomas. Arch Gynecol Obstet. 2005:271:104-8.

149. Loren AW, Mangu PB, Beck LN, Brennan L, Magdalinski AJ, Partridge AH, et al. Fertility preservation for patients with cancer: American Society of Clinical Oncology clinical practice guideline update. J Clin Oncol. 2013;31:2500-10.

150. Kesic V, Rodolakis A, Denschlag D, Schneider A, Morice P, Amant F, et al. Fertility preserving management in gynecologic cancer patients: the need for centralization. Int J Gynecol Cancer. 2010;20:1613-9.

151. Routine Screening for Hereditary Breast and Ovarian Cancer Recommended. American Congress of Obstetricians and Gynecologists. March 23, 2009. Available at: http://www.acog.org/About-ACOG/News-Room/News-Releases/2009/RoutineScreening-for-Hereditary-Breast-and-Ovarian-Cancer-Recommended. Accessed Apr 2015.

152. Kim J, Turan V, Oktay K. Long-term safety of letrozole and gonadotropin stimulation for fertility preservation in women with breast cancer. J Clin Endocrinol Metab. 2016;101:1364-71.

153. Quinn GP, Vadaparampil ST, Bower B, Friedman S, Keefe DL. Decisions and ethical issues among BRCA carriers and the use of preimplantation genetic diagnosis. Minerva Med. 2009;100:371-83.

154. Oktay K, Kim JY, Barad D, Babayev SN. Association of BRCA1 mutations with occult primary ovarian insufficiency: a possible explanation for the link between infertility and breast/ovarian cancer risks. J Clin Oncol. 2010;28:240-4.

\section{Submit your next manuscript to BioMed Central and we will help you at every step:}

- We accept pre-submission inquiries

- Our selector tool helps you to find the most relevant journal

- We provide round the clock customer support

- Convenient online submission

- Thorough peer review

- Inclusion in PubMed and all major indexing services

- Maximum visibility for your research

Submit your manuscript at www.biomedcentral.com/submit

C Biomed Central 